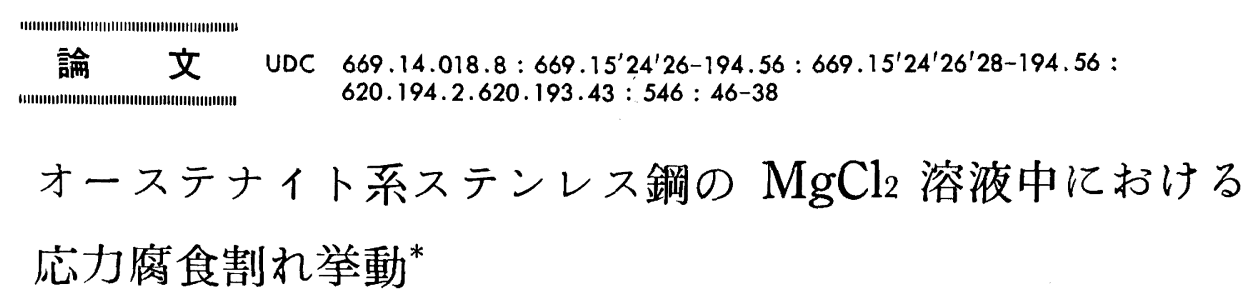

小若 正 倫**.工 藤 趃 夫***

\title{
Stress Corrosion Cracking Behavior of Austenitic Stainless Steels in $\mathrm{MgCl}_{2}$ Solutions
}

\author{
Masamichi KowAKA and Takeo KuDo
}

\section{Synopsis:}

Stress corrosion cracking behavior of SUS 304 and SUS 316 stainless steels was investigated in terms of concentration and temperature of $\mathrm{MgCl}_{2}$ solutions with or without dissolved oxygen. The potential$\mathrm{MgCl}_{2}$ concentration relation between $\mathrm{SCG}$ and pitting corrosion was also studied by constant potential method under the applied stress of $25 \mathrm{~kg} / \mathrm{mm}^{2}$.

As dissolved oxygen becomes necessary to cause SCG with decreasing the concentration or the temperature of $\mathrm{MgCl}_{2}$ solutions, SUS 316 becomes much more resistant to SCG than SUS 304 . The crack is often observed originating at the bottom of a pit.

The lower limit of $\mathrm{MgCl}_{2}$ concentration above which cracks develop at $80^{\circ} \mathrm{G}$ is about $20 \%$ for SUS 304 and about $25 \%$ for SUS 316 , while the critical SCC potential of SUS 316 is about $50 \mathrm{mV}$ more noble than that of SUS 304. Above the lower limit of $\mathrm{MgCl}_{2}$ concentration, the corrosion mode shifts from SCC to pitting corrosion as the applied potential is raised and the SCG potential range widens with increasing $\mathrm{MgCl}_{2}$ concentration. Below that, only pitting corrosion occurs.

\section{1. 緒}

言

塩化物水溶液中におけるオーステナイト系ステンレス 鋼の応力腐食㓶孔については, 従来より多くの研究結果 が報告されている、なかでも，SCHEIL が沸滕 $42 \%$ $\mathrm{MgCl}_{2}$ 溶液（ $\left.154^{\circ} \mathrm{C}\right)$ に打けるステンレス鋼の応力腐食 割れ試験をおこなつて以来, 多くの研究がこの試験液に ておこなわれてきた。しかし，沸滕 $42 \% \mathrm{MgCl}_{2}$ 溶液は 酸性で腐食性がきびしいため，実用上問題となる中性塩 水溶液での応力腐食割れとは必ずしもその挙動を同じく するとはい充い。

成分元素の影響については, 沸腾 $42 \% \mathrm{MgCl}_{2}$ 溶液中 と高温高压水中でその影響が異なり，例えば，Cは前者 では有効であるが1) 6)，後者では非常に有害な元素とな る7)8)。また，高浱度塩化物水溶液のうちでも，沸騰 42 $\% \mathrm{MgCl}_{2}$ 溶液と沸腾 $20 \% \mathrm{NaCl}$ 溶液9)では成分元素の
影響が異なる、筆者らは沸騰 $\mathrm{MgCl}_{2}$ 溶液の濃度によつ ても成分元素の影響が変化すること定明らかにした ${ }^{10)}$. 溶存酸素は沸騰 $42 \% \mathrm{MgCl}_{2}$ 溶液中での応力腐食割れ に対しては必ずしも必要でないが11)，中性塭水溶液中で は不可欠である．特に，高温高压水中では溶存酸素の影 響が大きく，0.1ppm 以上になると応力腐食割れをおこ しやすくなることが明らかにされている1213).

また, 沸騰 $42 \% \mathrm{MgCl}_{2}$ 溶液中では応力腐食割れが孔 食を起点として発生するここはないが，中性塩水溶液中 では孔食を起点として発生する場合が多(9)14) - 16).

このように両環境で応力腐食割れ挙動を大きく異にす るが，これらの相異を系統的に検討した研究は少なく， 不明な点も多い.

そこで，本報では応力腐食割れにおよぼす溶存酸素の 影㗽ならびに応力腐食剕れと孔食の関係に主眼をおいて 沸䓵 $42 \% \mathrm{MgCl}_{2}$ 溶液から䟴度および温度を低下させ，

* 昭和49 年11月本会龇演大会䣓論会にて発表 昭和50年 5 月12日受付 (Received May 12, 1975)

** 住友众属工業(株)中央技術研究所 理博 (Central Research Laboratory, Sumitomo Metal Industries, Ltd.)

*** 住友余属工获(株) 中央技術研究所 (Central Research Laboratory, Sumitomo Metal Industries, Ltd. 1-3 Nishinagasu-hondori Amagasaki 660) 
Table 1. Chemical compositions of materials used (wt $\%)$.

\begin{tabular}{l|c|c|c|c|c|c|c|c|c|c}
\hline Steels & $\mathrm{C}$ & $\mathrm{Si}$ & $\mathrm{Mn}$ & $\mathrm{P}$ & $\mathrm{S}$ & $\mathrm{Cu}$ & $\mathrm{Ni}$ & $\mathrm{Cr}$ & $\mathrm{Mo}$ & $\mathrm{N}$ \\
\hline SUS 304 & 0.053 & 0.52 & 1.69 & 0.023 & 0.005 & 0.03 & 9.39 & 19.13 & 0.05 & 0.03 \\
SUS 316 & 0.052 & 0.33 & 1.65 & 0.020 & 0.005 & 0.22 & 13.49 & 16.46 & 2.11 & 0.022 \\
\hline
\end{tabular}

中性塩水溶液に移行させていつた場合に，割れの挙動が いかに変化するかを検討し，同時に，応力腐食割れと孔 食の相異について考察を加えた.

\section{2. 実 験 方 法}

\section{$2 \cdot 1$ 供 試 材}

試験材として用いた SUS 304 および SUS 316 の化 学組成を Table 1 に示す. 市販のパイプ材を偏平泠延 後, $1100^{\circ} \mathrm{C} \times 30 \mathrm{~min}$ 水冷の溶体化処理をおこない, 平 行部 $3 \phi \times 20 \mathrm{~mm}$ の引張型試験片㧍よび $2 \times 10 \times 75 \mathrm{~mm}$ の短冊型試験片を作製した。これらの試験片をエメリー 紙 $\sharp 0$ 研摩後, 機械加工の影管を取り除くことを目的と して, 真空中にて $1100^{\circ} \mathrm{C} \times 10 \mathrm{~min}$ の応力除去焼鈍を おこなつた．その後表面皮膜除去のため，短冊型試験片 については軽くエメリ一紙 $\sharp 0$ 研摩を, 引張試験片につ いては, りえ酸 6 容, 硫酸 3 容, 水 1 容およびク口ム酸 $50 \mathrm{~g} / l$ の混合液中で, 電流密度 $0.5 \mathrm{~A} / \mathrm{cm}^{2}$ で電解研摩 をおこない，実験に供した。

\section{$2 \cdot 2$ 実験方法}

応力腐食割れにおよぼす $\mathrm{MgCl}_{2}$ 溶液の浱度, 温度打 よび溶存酸素の影響を 20 ～ $45 \%$ の沸腾 $\mathrm{MgCl}_{2}$ 溶液およ び $25 \sim 45 \% \mathrm{MgCl}_{2}, 80 \sim 120^{\circ} \mathrm{C}$ で各々酸素飽和㧍よび 脱気 $\left(\mathrm{N}_{2}\right.$ による) の水溶液中で恰討した．この溶液中に 上記短冊型試験片をU字型に曲げて $5 \mathrm{~mm}$ 拘束した試験 片を浸漬して試験した、試験時間は $300 \mathrm{hr}$ とした。また 一部の条件については, 引張型試験片を用いて定荷重下 で破断時間を測定した。この場合は, 酸素飽和の代りに 通気状態で試験をおこなつた。いずれの場合にも，試験 後試験片の断面の顕微鏡観察をおこなつて，制れの有無 および腐食形態を調べな。

応力腐食割れと孔食の電位的関係を明らかに方るた め，15〜35\% $\mathrm{MgCl}_{2} ， 80^{\circ} \mathrm{C}$ の通気あるいは脱気した溶 液中で定電位に保持して，腐食形態におよぼす電位の影 響を調べた：溶液の $\mathrm{pH}$ 調整はおこなわなかつたが，35

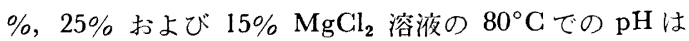
それぞれ 3.95，4.83，5.50であつた。照合電極として 飽和カロメル電極を用い，試駼液と同濃度の室温 $\mathrm{MgCl}_{2}$ 溶液を介して測定した．試験片としては引張型試験片を 用い，付加応力は $25 \mathrm{~kg} / \mathrm{mm}^{2}$ とした。

\section{3. 実 験 結 果}

\section{$3.1 \mathbf{M g C l}_{2}$ 溶液の濃度, 温度および溶存酸素の影響}

SUS 304 および SUS 316 の応力應食割れにおよぼ す $\mathrm{MgCl}_{2}$ 溶液の浱度, 温度および溶存酸素の影響をU 字曲げ法により檢討した，結果をそれぞれ Fig. 1 およ び Fig. 2 に示す。なお，洲鶑 $\mathrm{MgCl}_{2}$ 溶液中の結果は 脱気状態として表示した. SUS 304 の場合, 脱気状態て は割れ発生の下限は約 $100^{\circ} \mathrm{C}$ である。酸素咆和の状態 ではさらに低温まで制れを発生する。一方，SUS 304 に 比べて耐孔食性の高いSUS 316 は応力腐食㓶れに対し ても抵抗性が高いことがわかる。すなわち，脱気状態て は約 $120^{\circ} \mathrm{C}$ が割れ発生の下限であり，酸素飽和の状態 にすると，下限は若干低下するが，SUS 304 に比べて高 温である.

$45 \% \mathrm{MgCl}_{2}, \quad 120^{\circ} \mathrm{C}$ 打よび $25 \% \mathrm{MgCl}_{2}, 80^{\circ} \mathrm{C}$ の 溶液中で定荷重法により検討した結果をそれぞれFig. 3 および Fig. 4 亿示声. $45 \% \mathrm{MgCl}_{2}, 120^{\circ} \mathrm{C}$ の溶液中

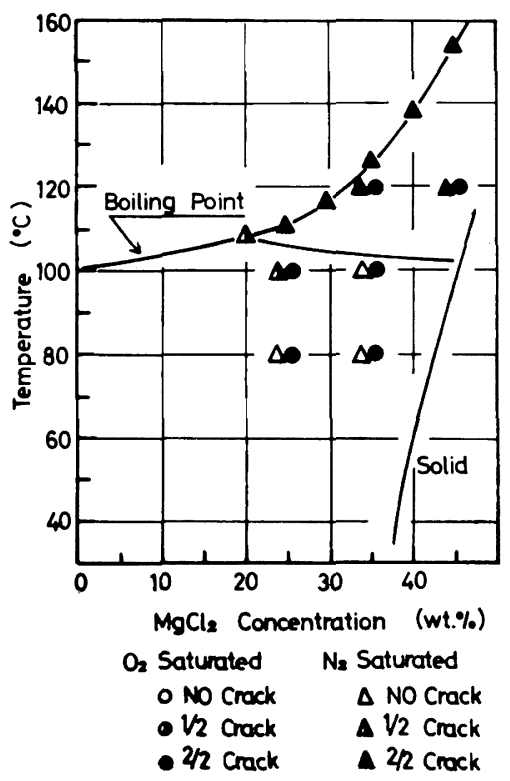

Fig. 1. Effect of concentration, temperature and dissolvd oxygen on stress corrosion cracking of SUS 304 stainless steel in $\mathrm{MgCl}_{2}$ solutions (U-bend). 


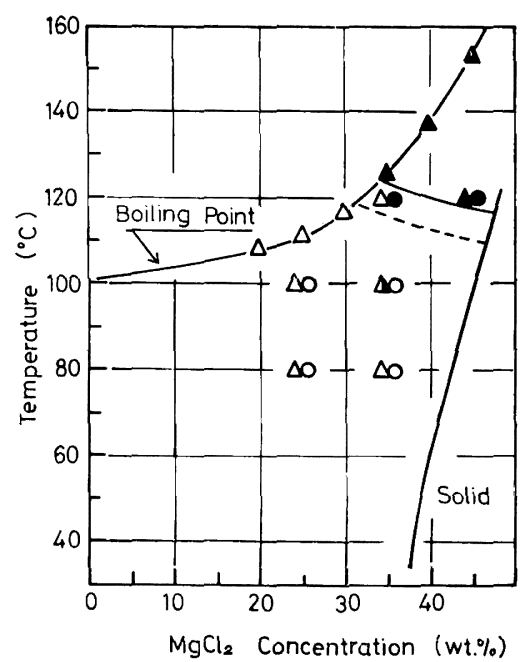

Fig. 2. Effect of concentration, temperature and dissolved oxygen on stress corrosion cracking of SUS 316 stainless steel in $\mathrm{MgCl}_{2}$ solutions (U-bend))

Symbols show the same meaning as in Fig. 1 .

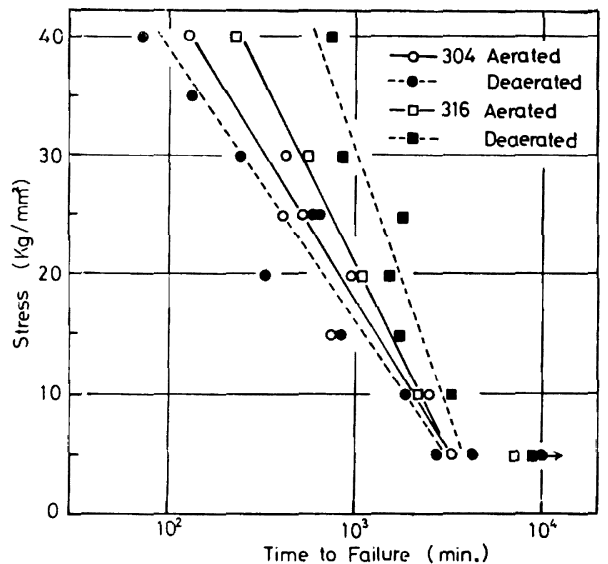

Fig. 3. Stress corrosion cracking of SUS 304 and SUS 316 stainless steels in $45 \% \mathrm{MgCl}_{2}$ solution at $120^{\circ} \mathrm{C}$.

では溶存酸素の影響は顕著でない. SUS 304 の場合, 脱 父状態の方が若干破断時間が短かくなつているが，この 原因は明らかでない，SUS 316 は通気状態の方が破断時 間が短かい，一方，25\% $\mathrm{MgCl}_{2} ， 80^{\circ} \mathrm{C}$ の溶液中では通 父状態のSUS 304 の及㓶れが生じた. 割れ発生に溶存 酸素が必要であることを示している.

SUS 304 の典型的な㓶れを Photo. 1 に示す. 45\% $\mathrm{MgCl}_{2}, 120^{\circ} \mathrm{C}$ の溶液では孔食の発生は認められず, 表

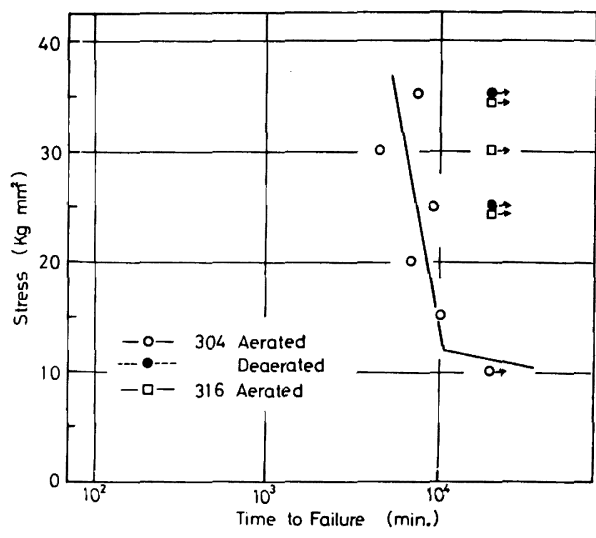

Fig. 4. Stress corrosion cracking of SUS 304 and SUS 316 stainless steels in $25 \% \mathrm{MgCl}_{2}$ solution at $80^{\circ} \mathrm{C}$.

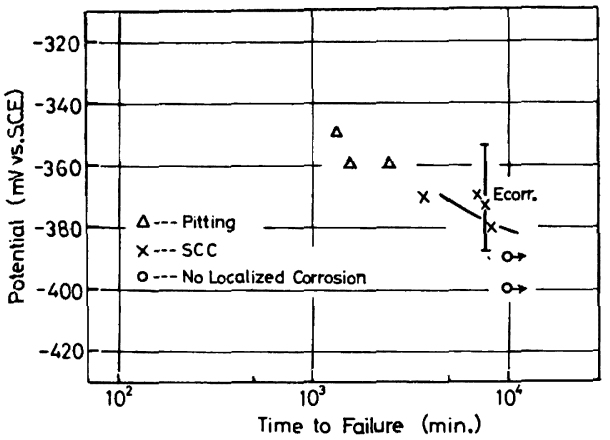

Fig. 5. Effect of applied potential on time to failure of SUS 304 stainless sieel in aerated $25 \% \mathrm{MgCl}_{2}$ solution at $80^{\circ} \mathrm{C}\left(25 \mathrm{~kg} / \mathrm{mm}^{2}\right)$.

面から割れが生じている.一方， $25 \% \mathrm{MgCl}_{2}, 80^{\circ} \mathrm{C}$ の 溶液では孔食を起点として割れが発生しているのが認め られる。一般的な傾向として， $\mathrm{MgCl}_{2}$ 溶液の濃度およ び温度が低下するにつれて孔食を起点とした割れが多く 観察されるようになり，また，その孔食も大きくなる傾 向にある。

\section{2 応力腐食割れと孔食の電位的関係}

応力腐食割れと孔食の電位的関係を明らかにする目的 で, $80^{\circ} \mathrm{C}$ の $\mathrm{MgCl}_{2}$ 溶液中で定電位に保持して試験を おこなつた，通気した $25 \% \mathrm{MgCl}_{2}$ 溶液中での SUS 304 の試験結果を Fig. 5 に示す. ただし, 図中で応力腐食 㓶れと孔食が共存する場合には割れとして表示し，割れ の生じうる電位領域を求めた. $25 \% \mathrm{MgCl}_{2}$ 溶液中での 割れ発生の電位は一 域においてであり，それ以上高めるともはや割れは発生 せず，孔食のみを生ずる，それに対して，自然電位は約 


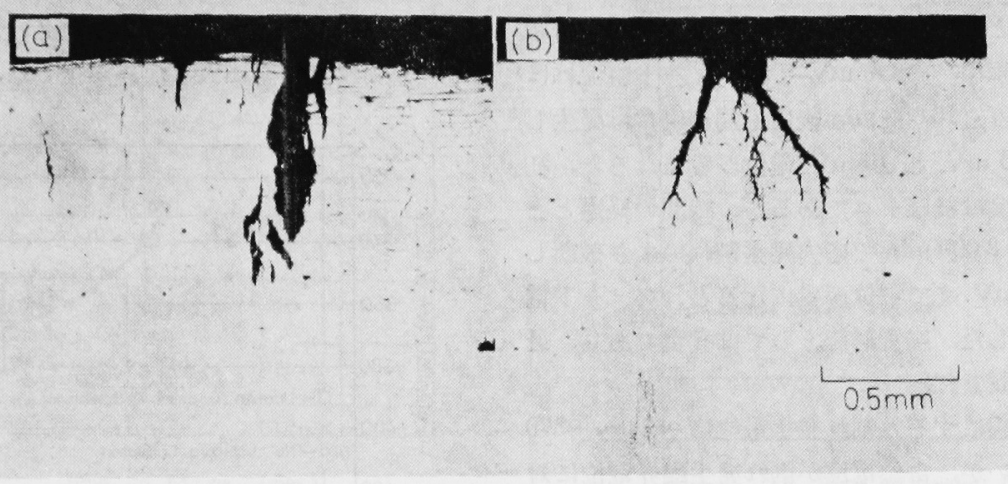

$\begin{array}{ll}\text { (a) } 45 \% \mathrm{MgCl}_{2}, 120^{\circ} \mathrm{C} & \text { (b) } 25 \% \mathrm{MgCl}_{2}, 80^{\circ} \mathrm{C}\end{array}$

Photo. 1. Stress corrosion cracking of SUS 304 stainless steel in aerated $\mathrm{MgCl}_{2}$ solutions $\left(25 \mathrm{~kg} / \mathrm{mm}^{2}\right)$.

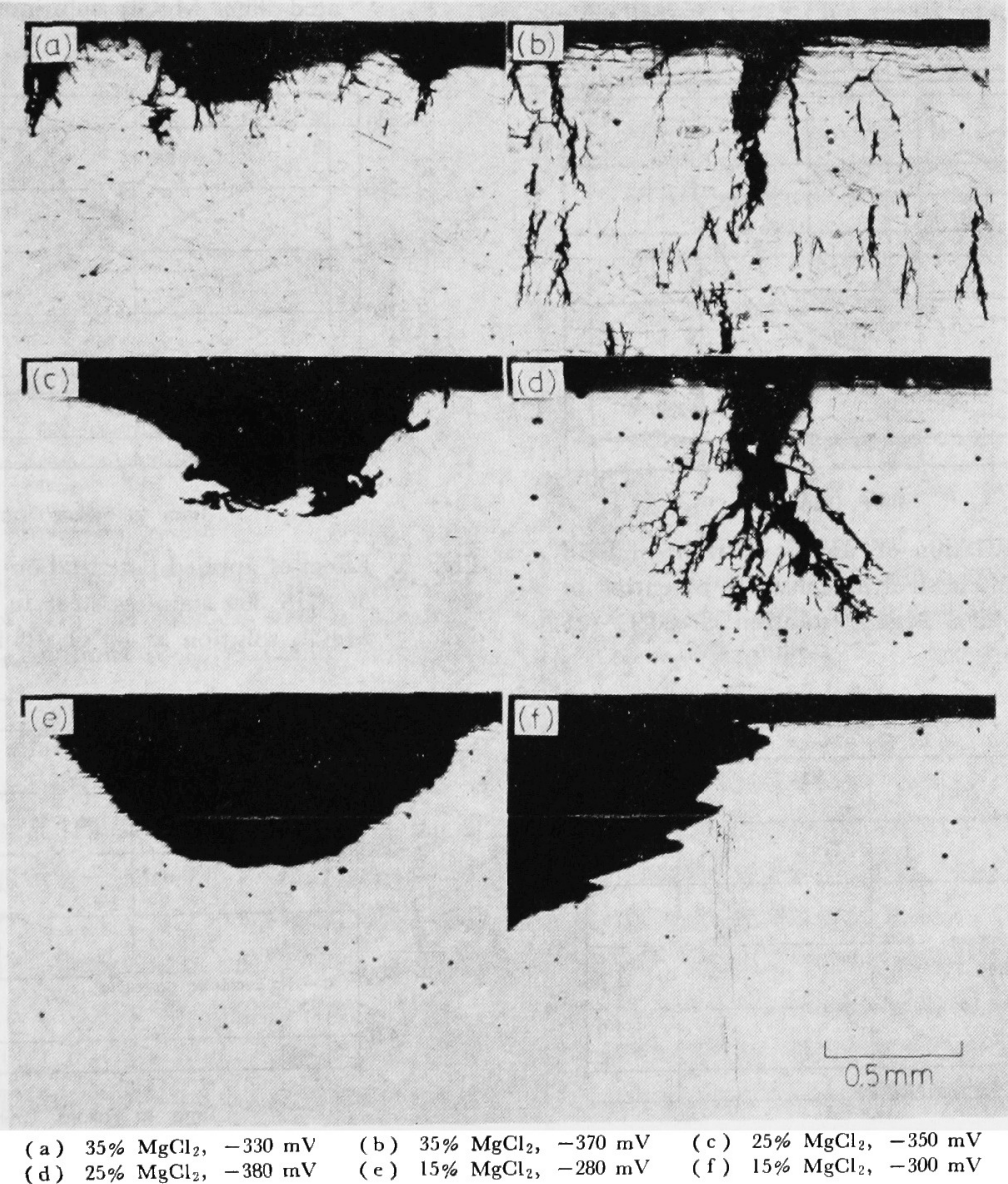

Photo. 2. Effect of applied potential on corrosion mode of SUS 304 stainless steel in aerated solutions at $80^{\circ} \mathrm{C}\left(25 \mathrm{~kg} / \mathrm{mm}^{2}\right)$. 
-390〜 - 360 mV 付近にあり，割れと孔食の両電位領 域に存在することがわかる. Fig. 6 にそのときの電流密 度の経時変化を示す. $-390 \mathrm{mV}$ ではアノード電流はほ とえどゼロであり，10000 min 後にも局部應食溌生し なかつた. $-380 \mathrm{mV}$ と $10 \mathrm{mV}$ 電位が責になると, 初 期のアノード電流はほぼゼロであるが，時間の経過とと もに増加し, 約 $8000 \mathrm{~min}$ で応力腐食割れにより破断し た. 一方 $-360 \mathrm{mV}$ まで電位が貴になると，アノード電 流は急激に増大した。腐食形態としては孔食であり, 最 終的には延性破断した.

一方, 脱気状態にすると割れ発生電位は-380〜 - 370 $\mathrm{mV}$ と変化しないが，自然電位が割れ発生臨界電位に対 して 10〜20 mV とわずかであるが早な值を示した(Fig.

7 ). 溶存酸素は自然電位を臨界電位以上に高める作用 として説明できる.

通気した $25 \% \mathrm{MgCl}_{2}$ 溶液中での腐食形態におよぼす 電位の影響を Photo. $2(c)$, (d)に示す. $-350 \mathrm{mV}$ に

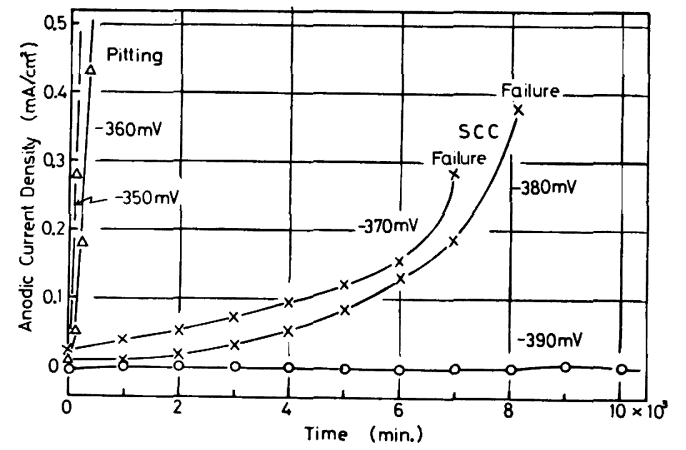

Fig. 6. Time variation of anodic current of SUS 304 stainless steel at constant potential in aerated $25 \% \mathrm{MgCl}_{2}$ solution at $80^{\circ} \mathrm{C}(25$ $\mathrm{kg} / \mathrm{mm}^{2}$ ).

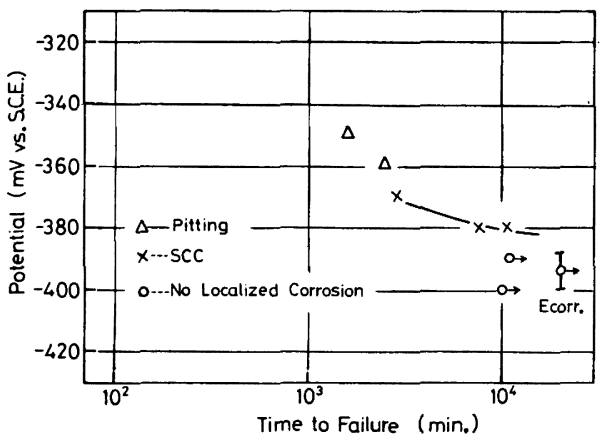

Fig. 7. Effect of applied potential on time to failure of SUS 304 stainless steel in deaerated $25 \% \mathrm{MgCl}_{2}$ solution at $80^{\circ} \mathrm{C}\left(25 \mathrm{~kg} / \mathrm{min}^{2}\right)$.
保持すると孔食のみ発生するが，一 $-380 \mathrm{mV}$ にすると孔 食を起点とした応力腐食割れを生じ, わずか $30 \mathrm{mV}$ の 電位差で腐食形態に大きな差が生じる.

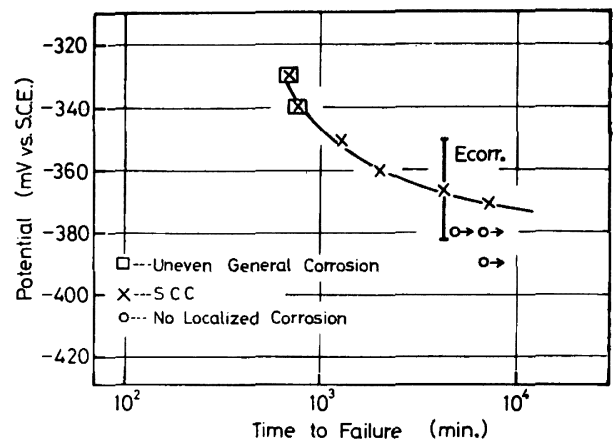

Fig. 8. Effect of applied potential on time to failure of SUS 304 stainless steel in aerated $35 \% \mathrm{MgCl}_{2}$ solution at $80^{\circ} \mathrm{C}(25$ $\mathrm{kg} / \mathrm{mm}^{2}$ ).

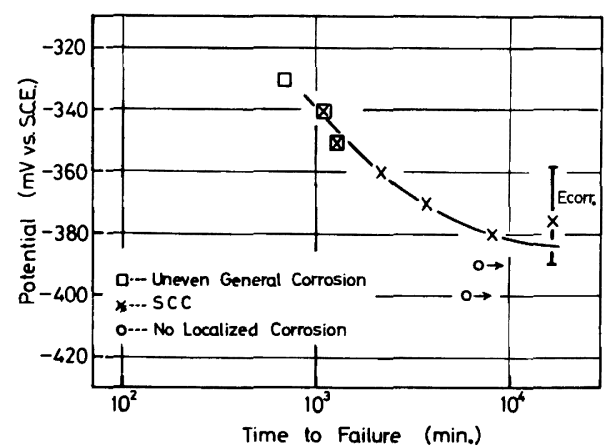

Fig. 9. Effect of applied potential on time to failure of SUS 304 stainless steel in aerated 30\% $\mathrm{MgCl}_{2}$ solution at $80^{\circ} \mathrm{C}\left(25 \mathrm{~kg} / \mathrm{mm}^{2}\right)$.

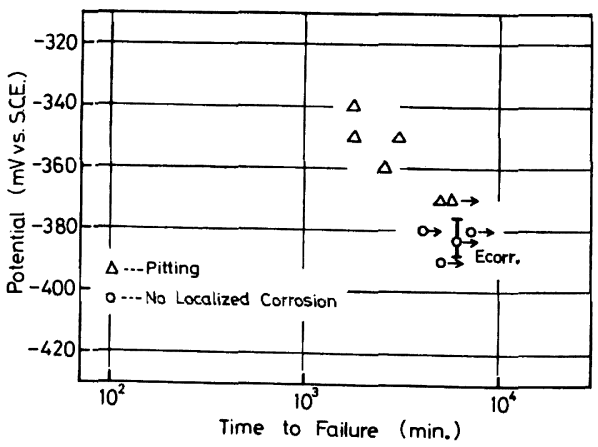

Fig. 10. Effect of applied potential on time to failure of SUS 304 stainless steel in aerated $20 \% \quad \mathrm{MgCl}_{2}$ solution at $80^{\circ} \mathrm{C}$ $\left(25 \mathrm{~kg} / \mathrm{mm}^{2}\right)$. 


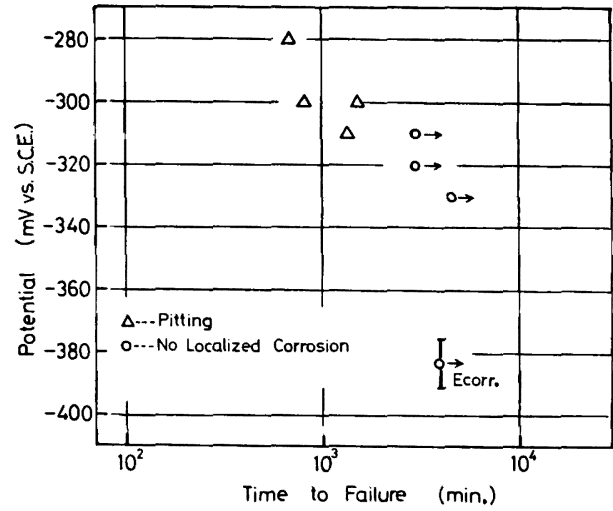

Fig. 11. Effect of applied potential on time to failure of SUS 304 stainless steel in aerated $15 \% \mathrm{MgCl}_{2}$ solution at $80^{\circ} \mathrm{C}\left(25 \mathrm{~kg} / \mathrm{mm}^{2}\right)$.

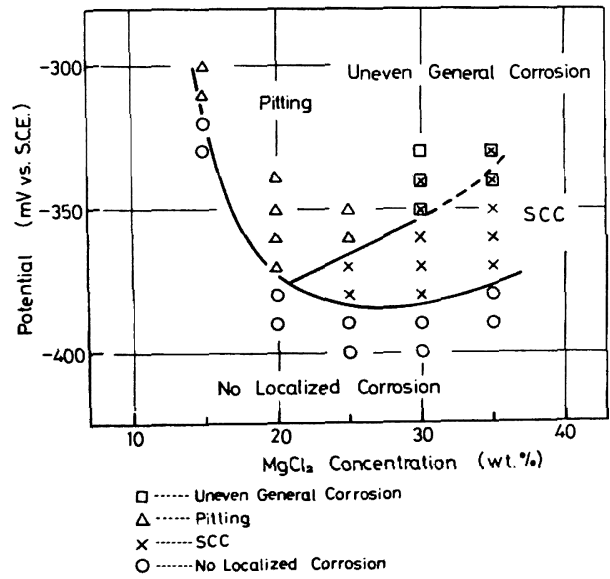

Fig. 12. Relation between SCC and pitting corrosion of SUS 304 stainless steel in aerated $\mathrm{MgCl}_{2}$ solutions at $80^{\circ} \mathrm{C}\left(25 \mathrm{~kg} / \mathrm{mm}^{2}\right)$.

次に, $\mathrm{MgCl}_{2}$ 溶液の濃度の影響を通気した $80^{\circ} \mathrm{C}$ の 溶液中で検討した. SUS 304 について，濃度を高め 35 $\%$ おび $30 \% \mathrm{MgCl}_{2}$ 溶液とした場合の結果を Fig. 8 および Fig. 9 に示す。割れ発生の電位領域は $25 \%$ $\mathrm{MgCl}_{2}$ 溶液に比べて広くなる. $30 \% \mathrm{MgCl}_{2}$ 溶液の場合 -380〜 - $340 \mathrm{mV}$ の電位領域で，また， $35 \% \mathrm{MgCl}_{2}$ 溶 液の場合 $-370 \mathrm{mV}$ 以上で割れが認められた。しかし， Photo. 2 (a),（b ）に $35 \% \mathrm{MgCl}_{2}$ 溶液での腐食形態 を示すように，電位が貴になるにつれて表面は凹凸の激 しい全面腐食的形態を示した.

一方，濃度を低下させ $20 \%$ および $15 \% \mathrm{MgCl}_{2}$ 溶液 とした場合の結果を Fig. 10 および Fig. 11 に示す. 割れの発生は全く認められず，孔食のみ発生した。 孔食

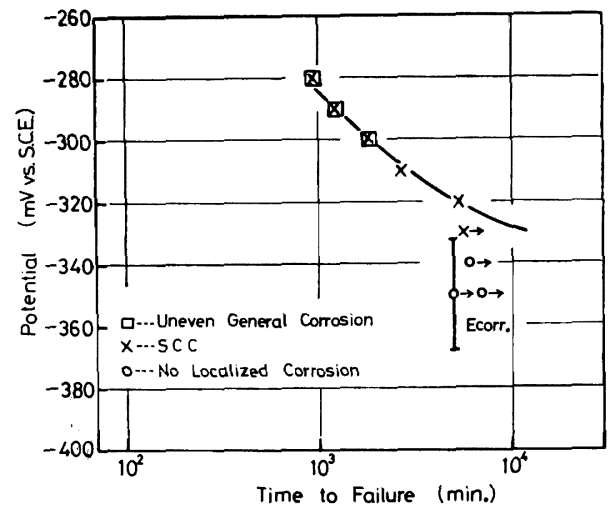

Fig. 13. Effect of applied potential on time to failure of SUS 316 stainless steel in aerated $35 \% \mathrm{MgCl}_{2}$ solution at $80^{\circ} \mathrm{C}\left(25 \mathrm{~kg} / \mathrm{mm}^{2}\right)$.

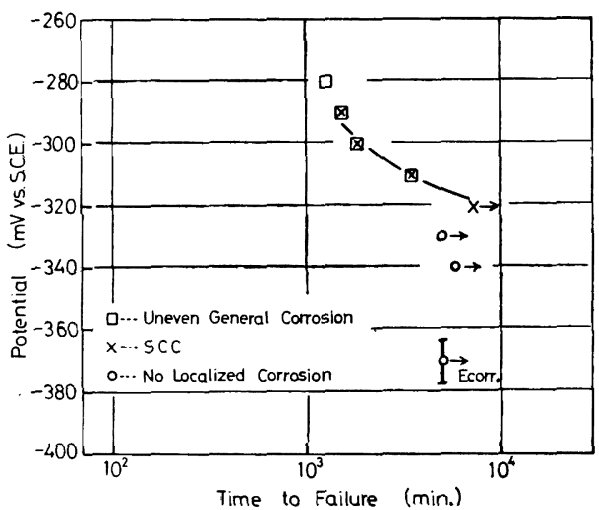

Fig. 14. Effect of applied potential on time to failure of SUS 316 stainless steel in aerated $30 \% \mathrm{MgCl}_{2}$ solution at $80^{\circ} \mathrm{C}(25$ $\left.\mathrm{kg} / \min ^{2}\right)$.

発生電位として $20 \% \mathrm{MgCl}_{2}$ 溶液ではー $370 \mathrm{mV}, 15 \%$ $\mathrm{MgCl}_{2}$ 溶液では $-310 \mathrm{mV}$ が得られた. しかし, $15 \%$ $\mathrm{MgCl}_{2}$ 溶液の場合, $-310 \mathrm{mV}$ 以下でもシール部に隙間 腐食が観察される場合があつた. $15 \% \mathrm{MgCl}_{2}$ 溶液中に おける代表的な腐食形態を Photo. 2 ( e ), ( f )に示す.

以上述べた結果を $\mathrm{MgCl}_{2}$ 溽度と電位の関係でまとめ Fig. 12 に示す、約 $20 \% \mathrm{MgCl}_{2}$ 以上で割れを発生する 電位領域が存在し, 濃度が高まるにつれてその電位領域 は広がる傾向にある. 促進試験に用いられる沸騰 $42 \%$ $\mathrm{MgCl}_{2}$ 溶液中では応力腐食割れのみが観察されるのは この結果より推察できる. 一方, 濃度が約 $20 \%$ 以下に なると, もはや割れの発生は認められなくなり，孔食の みが生ずる。 


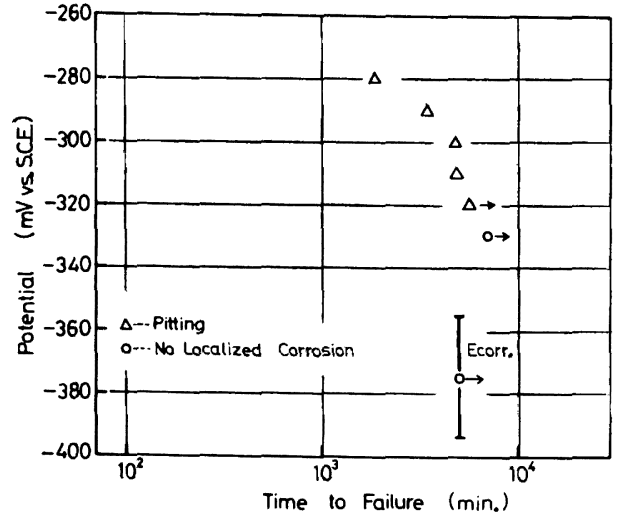

Fig. 15. Effect of applied potential on time to failure of SUS 316 stainless steel in aerated $25 \% \mathrm{MgCl}_{2}$ solution at $80^{\circ} \mathrm{C}(25$ $\left.\mathrm{kg} / \mathrm{mm}^{2}\right)$.

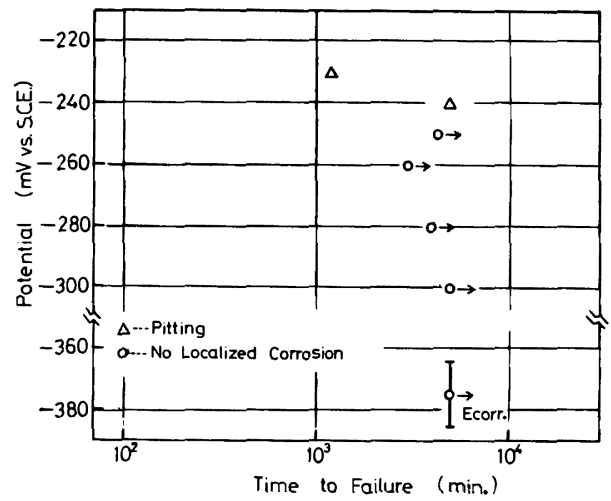

Fig. 16. Effect of applied potential on time to failure of SUS 316 stainless steel in aerated $20 \% \mathrm{MgCl}_{2}$ solution at $80^{\circ} \mathrm{C}(25$ $\left.\mathrm{kg} / \mathrm{mm}^{2}\right)$.

SUS 316 について同様に通気した $80^{\circ} \mathrm{C}$ の $\mathrm{MgCl}_{2}$ 溶 液中で検討した. $35 \%$ 20\% $\mathrm{MgCl}_{2}$ 溶液中での結果を Fig. 13〜16 亿示す. 応力腐食割れは $35 \% \mathrm{MgCl}_{2}$ 溶液 ではー330 $\mathrm{mV}$ 以上で，また， $30 \% \mathrm{MgCl}_{2}$ 溶液では ー320〜ー290 mV で発生した. しかし, 電位が貴になる につれて表面が全面腐食的形態を示すのは SUS 304 の 場合と同様である.一方，濃度が $25 \%$ および $20 \%$ $\mathrm{MgCl}_{2}$ となると割れを発生する電位領域は存在せず, 孔 食のみ発生した。 孔食発生電位として $25 \% \mathrm{MgCl}_{2}$ 溶液 では $-320 \mathrm{mV}, 20 \% \mathrm{MgCl}_{2}$ 溶液では $-240 \mathrm{mV}$ が得 られた。また，自然電位はいずれの場合にも割れ発生臨 界電位孔および食発生電位よりも㫣な值を示した．SUS 316 はこれらの溶液中では応力腐食割れおよび孔食を発

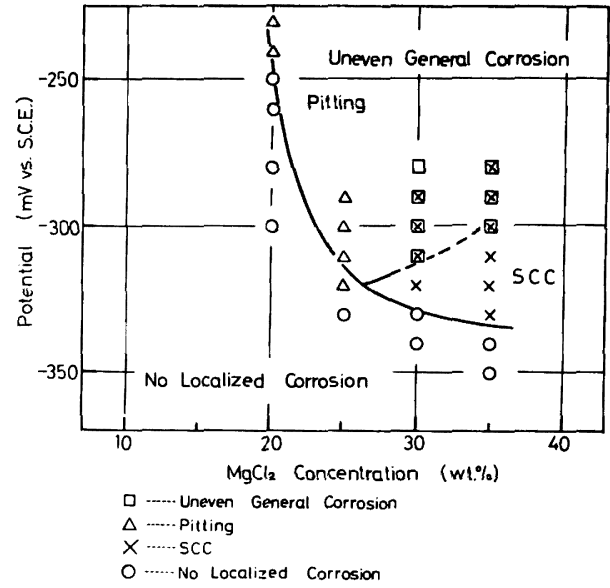

Fig. 17. Relation between SCC and pitting corrosion of SUS 316 stainless steel in aerated $\mathrm{MgCl}_{2}$ solutions at $80^{\circ} \mathrm{C}(25 \mathrm{~kg} /$ $\left.\mathrm{mm}^{2}\right)$.

\section{生しないことがわかる.}

SUS 316 について以上述べた結果を $\mathrm{MgCl}_{2}$ 濃度と電 位の関係でをと以 Fig. 17 に示す。割れを生じうる下 限濃度は約 $25 \% \mathrm{MgCl}_{2}$ であり, SUS 304 に比べて高 濃度である。また，割れ発生臨界電位としてー330〜320 $\mathrm{mV}$ が得られた. SUS 304 に比べて約 $50 \mathrm{mV}$ 貴な電 位である. $35 \%$ および $25 \% \mathrm{MgCl}_{2}$ 溶液中における代 表的な腐食形態を Photo. 3 に示す.

\section{4. 考察}

SUS 304 および SUS 316 ステンレス鋼の応力腐食 割れにおよぼす $\mathrm{MgCl}_{2}$ 溶液の濃度, 温度および溶存酸 素の影響について検討した結果, 沸騰 $42 \% \mathrm{MgCl}_{2}$ 溶液 中で検討する限り割れ感受性に大差ないが，濃度および 温度を低下すると SUS 316 の抵抗性が SUS 304 に比 ベて大きくなることが明らかとなつた，また，Fig. 12 および Fig. 17 の結果からもそのことはうかがえる. すなわち, 応力腐食割れを生ずる $\mathrm{MgCl}_{2}$ の下限濃度が 液温 $80^{\circ} \mathrm{C}$ のとき, SUS 304 の場合には約 $20 \%$ である のに対して, SUS 316 の場合には約 $25 \%$ と高濃度とな る. さらにもう 1 点, 割れ発生の臨界電位が, $80^{\circ} \mathrm{C}$ の $\mathrm{MgCl}_{2}$ 溶液の場合, SUS 304 がー380 mV 付近である のに対して, SUS 316 は-330 mV 付近を示し, SUS 316 の方が約 $50 \mathrm{mV}$ 貴となる点である.

Mo は孔食発生電位を高めることはよく知られた事実 でめるが，応力腐食割れの臨界電位も同様に高めること が明らかになつた。 


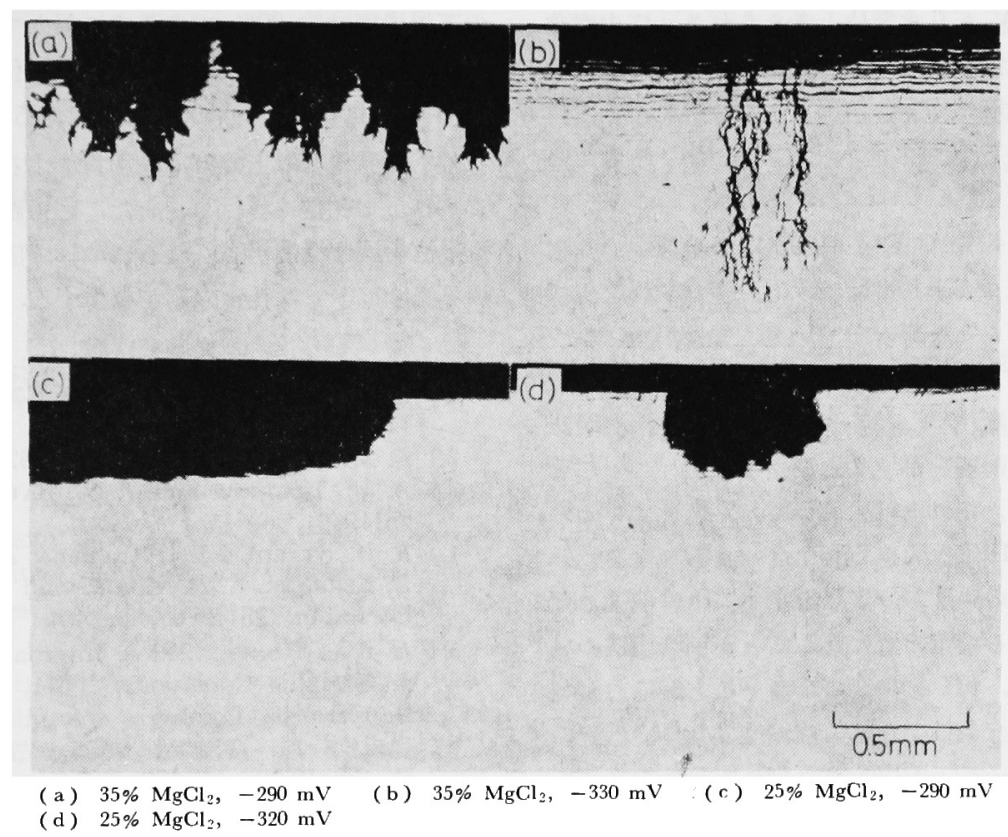

Photo. 3. Effect of applied potential on corrosion mode of SUS 316 stainless steel in aerated $\mathrm{MgCl}_{2}$ solutions at $80^{\circ} \mathrm{C}\left(25 \mathrm{~kg} / \mathrm{mm}^{2}\right)$.

さらに, $\mathrm{MgCl}_{2}$ 溶液の濃度および温度が低下するに つれて応力佰食割れ発生に溶存酸素が必要となることが 明らかになつた. SUS 304 では約 $100^{\circ} \mathrm{C}$ 以下の $\mathrm{MgCl}_{2}$ 溶液で溶存酸素が必要である. 溶存酸素は自然電位を割 れ発生の臨界電位以上に高める作用として説明できる.

Fig. 5 の通気状態および Fig. 7 の脱気状態の結果を比 較すれば明らかである。しかし，両者の自然電位を比較 するとき, 電位差はたかだか数 $10 \mathrm{mV}$ であり，例えば 室温海水中におけるほど自然電位におよぼす通気および 脱気の影響は顕著でない，これは高濃度 $\mathrm{MgCl}_{2}$ 溶液中 での酸素の溶解量が少ないことおよび高濃度 $\mathrm{MgCl}_{2}$ 溶 液が弱酸性であることに基因寸るものと考えられる，溶 存酸素量は塩化物の濃度および温度が高まるにつれて減

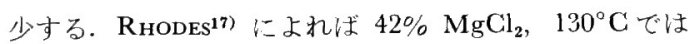
大気に接しているときの溶存酸素量は約 $0.3 \mathrm{ppm}$ と非 常に少ない。

Fig. 12 のSUS 304 の結果によれば，約 $20 \% \mathrm{MgCl}_{2}$ 以上で割れ孛生じうる電位領域が存在する。この濃度で の溶体酸素の役割は，前述したように自然電位を割れの 臨界電位以上に高めることにある。一方，濃度が約 $20 \%$ 以下になるともはや割れを生じうる電位領域が存在しな い。割れが発生するためには孔食が発生し，孔食内での CI- 濃縮求よび $\mathrm{pH}$ の低下が必要と考えられる. 孔食 内で $\mathrm{Cl}$ - が濃縮することおよび $\mathrm{pH}$ が低下することに
ついてはすでに明らかにされている18).この場合, 溶存 酸素の役割は応力腐食割れの前段階としての孔食の発生 に関与するものと考えられる。

Fig. 12 打よび Fig. 17 において, 応力腐食割れを生 じうる $\mathrm{MgCl}_{2}$ の下限濃度が存在することおよび電位を 高めるにつれて腐食形態として応力腐食割れから孔食に 移行し，しかも，その応力腐食割れを生じる電位領域が $\mathrm{MgCl}_{2}$ 溶液の濃度が高くなるにつれて広くなるという 事実は, 応力腐食割れの機構を考える上に执いて重要で ある・

最近, 応力腐食割れの内部の $\mathrm{pH}$ の測定が多くなされ ている19) 22). BAKER ${ }^{22)}$ は $125^{\circ} \mathrm{C} の \mathrm{MgCl}_{2}$ 溶液中で の SUS 304 の応力腐食割れ内部溶液の $\mathrm{pH}$ は常に 1.2 〜2.0 の一定值を示すことを明らかにした. そして, こ の原因を水素イオンの還元と溶出イオンの加水分解によ り説明している. pH が一定值定示すといらことは, 拡 散の制限された制れ先端部においては水素イオンの還元 と加水分解による水素イオンの生成が台ようど均衡を保 つていることを示している.

Fig. 6 に 25\% $\mathrm{MgCl}_{2}, 80^{\circ} \mathrm{C}$ に拈的 SUS 304 の 定電位に保持した時の電流密度の経時変化を示した。一 $360 \mathrm{mV}$ では電流は初期のほぼゼロから急激に增大し， 腐食形態としては孔食となる。一方, 応力腐食割れを発 生するー380〜ー370 $\mathrm{mV}$ では電流は增加するが微 少で 
ある. 約 $-360 \mathrm{mV}$ が孔食電位と考えられる. 応力腐食 割れはこの孔食電位よりもわずか早な電位の溶解が抑制 された状態で，金属イオンの溶出と加水分解による皮膜 の生成が均衡を保ちながら進行していくものと考元ら れる.

BRENNERT T $^{23}$ は $40 \% \mathrm{CaCl}_{2}, 100^{\circ} \mathrm{C}$ の溶液中で孔食 が発生する電位よりも果な電位に, 応力腐食割れを生ず る電位領域があることを報告している。またMURATA ${ }^{24)}$ らも硫酸中での応力腐食割れで同梯な結果を得ている.

高橋 ${ }^{25)}$ は高濃度塩化物, 特に高濃度 $\mathrm{MgCl}_{2}$ 溶液が非 常に小さい $\mathrm{pH}$ 續衝能を示すことを指摘した. このこと は拡散の制限された割れ内部において，水素イオンのわ ずかな収支でも $\mathrm{pH}$ 值を大きく変化させうること定し ている．割れ内部の $\mathrm{pH}$ が一定值を示すことは前述した が，逆に $\mathrm{pH}$ がある特定の値になることが割れ伝播の必 要条件と考总れば， $\mathrm{pH}$ 綑衝能の小さいことが応力腐食 割れ伝播に対して好条件となる。高濃度 $\mathrm{MgCl}_{2}$ 溶液の $\mathrm{pH}$ 緩衝能の小さいことが応力腐食割れ感受性を高めて いる一因と考えられる. また，Fig. 12 あるいは Fig. 17 において $\mathrm{MgCl}_{2}$ 溶液の濃度が高まるにつれて割れを生 じうる電位領域が広くなるのは $\mathrm{MgCl}_{2}$ 濃度が高くなる につれて $\mathrm{pH}$ 緩衝能が低下し，それだけ広い電位領域に わたつて応力腐食割れの伝播条件を満足しうるためと考 えられる. 逆に, $\mathrm{MgCl}_{2}$ 濃度が低下寸るにつれて孔食 のみ発生するのは，局部的な腐食が生じても，その局部 腐食個所の溶液が応力腐食割れの伝播条件を満足しえず 孔食として成長していくためと考えられる.

\section{5. 結}

\section{言}

SUS 304 および SUS 316 ステンレス鋼について, 応力腐食割れにおよぼす $\mathrm{MgCl}_{2}$ 溶液の濃度, 温度およ び溶存酸素の影響を，20〜 45\% の沸騰 $\mathrm{MgCl}_{2}$ 溶液およ び $25 \sim 45 \% \mathrm{MgCl}_{2}, 80 \sim 120^{\circ} \mathrm{C}$ の溶液中で検討した. 同時に，応力腐食割れと孔食の関係について，15〜35\% $\mathrm{MgCl}_{2}, 80^{\circ} \mathrm{C}$ の溶液中で定電位試験により検討を加え た. その結果，次の事柄が明らかとなつた。

1) $\mathrm{MgCl}_{2}$ 溶液の濃度打よび温度が低下するにつれ $\tau$, SUS 316 の応力腐食割れに対する抵抗性は SUS 304 に比べて著しく大きくなる.

2) SUS 304 は約 $100^{\circ} \mathrm{C}$ 以下の $\mathrm{MgCl}_{2}$ 溶液中では 割れ発生に対して溶存酸素が必要である. 溶存酸素は自 然電位を割れ発生の臨界電位より高める作用がある。 た，濃度および温度が低下するにつれて孔食を起点とし た割れが多く観察される.

3) $80^{\circ} \mathrm{C}$ の $\mathrm{MgCl}_{2}$ 溶液中では SUS 304 の割れ発生
の下限濃度は約 $20 \%$ であるのに対して，SUS 316 は約 $25 \%$ となる。 また，制れ発生の臨界電位は SUS 316 が SUS 304 に比べて約 $50 \mathrm{mV}$ 貴である.

4）限界濃度以上では電位を貴にするにつれて応力腐 食割れから孔食へ移行し，また，応力腐食割れを生じう る電位領域は濃度が高くなるにつれて広くなる。一方， 限界浱度以下では孔食のみが発生する。

\section{文献}

1) 小若正偷，冨士川尚男：日本金属学会誌，34 (1970), p. 1054

2) F. S. LANG: Corrosion, 18(1962), p. 378

3 ) $A . W$. Loginow and $J . F$. Bates: Corrosion, 25(1969), p. 15

$4) R$. $W$. Staehle, J. J. Royuela $T$. L. Raredon, E. Serrate, C. R. Morin, and $R$. V. Farrar: Corrosion, 26(1970), p. 451

5 ) D. Van Rooyen: First International Congress on Metallic Corrosion, (1961), p. 309, Butterworth, London

6 ）遅沢浩一郎，深瀬幸重，横田孝三：日本金属学会 誌, 36(1972), p. 170

7 ）伊藤伍郎，石原只雄，清水義彦：日本金属学会誌 $34(1970)$, p. 101

8 ）小若正倫，富士川尚男：日本金属学会請演概要集 (1972), p. 102

9 ）森田 茂：日本金属学会誌，25(1961)，p. 667

10）小若正倫，工藤越夫：日本金属学会誌, 37(1973), p. 1320

11) $H$. $H$. Uhlig and $J$. Lincoln: J. Electrochem. Soc., 105(1958), p. 325

12) W. L. Williams: Corrosion, 13 (1957), p. 539

13）杉本一六, 前川立夫, 香川優：防食技術, 14 (1965), p. 155

14）伊藤伍郎，石原只雄，清水義彦，日本金属学会誌 $30(1966)$, p. 888

15）下瀬高明，高村 昭，森 憲二，下郡一利：日本 金属学会誌, 27(1963), p. 530

16) $R . W$. Staehle, F. H. Beck, and M. G. FonTANA: Corrosion, 15(1959), p. 373

17) $P$. $R$. Rhodes: Corrosion, 25(1969), p. 462

18) $T$. Suzuki, $M$. Yamabe, and $Y$. Kitamura: Corrosion, 29(1973), p. 18

19) G. SAndoz, C. T. FujII, and B. F. Brown: Corros. Sci., 10(1970), p. 845

20) B. F. Brown, C. T. FujII, and E. P. DaklBERG: J. Electrochem. Soc., 116(1969), p. 218

21) $M$. Marek and $R$. F. Hochman: Corrosion, 26 (1970), p. 5

22) $H$. $R$. Baker, $M . C$. Bloom, $R$. $N$. Bolster, and $C . R$. Singleterry: Corrosion, 26(1970), p. 420

23) S. Brennert: Recent Advences in Stress Corrosion (1961), Royal Swedish Academy of Engineering Sciences, Stockholm

24) T. Murata and $R$. W. Staehle: The Theory of Stress Corrosion Cracking in Alloys, (1971), p. 223, NATO, Brussels

25）高橋正雄：防食技術，21(1972)，p. 199 